\title{
Maaltamuuton valikoivuudesta
}

Valtiot.kand. TAPANI VALKONEN ja

valtiot.kand. KAISA KUKKONEN, Helsingin yliopiston sosiologian laitos

Helsingin yliopiston sosiologian laitoksella aloitettiin vuonna 1963 tutkimussarja, jonka tarkoituksena on selvittää teollistumisen vaikutuksia maalaisyhteiskuntaan. Tutkimus suoritetaan pääasiallisesti Ristiinan kunnassa, jonne vuodesta 1963 lähtien on rakennettu puunjalostustehdasta (ks. Valkonen, 1965). Tämä artikkeli on osa tutkimussarjaa ja perustuu samaan aineistoon kuin Kaisa Kukkosen pro gradu-työ "Nuorison maaltamuutto, tutkimus nuorison muutosta Ristiinan kunnassa vuosina 1950 - 63" . Pro gradu-työn tarkoituksena oli selvittää nuorison maaltamuuton määrää ja laatua Ristiinassa ennen kunnan teollistumista niin, että saataisiin vertailuaineistoa myöhempiä teollistumisen vaikutuksia koskevia tutkimuksia varten.

Aineiston avulla voidaan tutkia myös sitä, millaiset nuoret muuttavat pois maaseudulta. Tässä artikkelissa pyritään erityisesti selvittämään, eroavatko muuttavat nuoret lahjakkuudeltaan tai kyvykkyydeltään paikallaan pysyvistä. Kuten Wilbert E. Moore $(1963,332)$ toteaa, usein on esitetty kaksi toisilleen vastakkaista näkemystä: toisen mukaan maaseudulta jatkuvasti ohjautuvat lahjakkaimmat nuoret kaupunkeihin, toisen mukaan taas maaseudulla epäonnistuneet ajautuvat $\mathrm{mm}$. taloudellisten syiden vuoksi kaupunkeihin. Koska molemmille näkökannoille löytyy jonkin verran tukea eri maissa suoritetuista tutkimuksista, ei luultavasti voida löytää mitään yleistä kaikkia yhteiskuntia koskevaa säännönmukaisuutta. Sen vuoksi esitetään seuraavassa vain Suomessa ja Ruotsissa tehtyjä ongelmaa koskevia tutkimuksia.

Allardt, Jartti, Jyrkilä ja Littunen (1958, 180-181) ovat tutkineet muuttoliikkeen valikoivuutta tiedollisen aktiivisuuden asteikon avulla. Tutkimuksen mukaan maaseudulta kaupunkiin tapahtuva muuttoliike valikoi enemmän tiedollisesti vireätä ainesta kuin maaseutujen välinen tai kaupungista maaseudulle suuntautuva muuttoliike. Lisäksi päätellään, että maaseudulta kaupunkiin päin kulkee merkitsevästi enemmän sosiaalisesti „voimakasta" kuin "heikkoa" nuorisoa. Kai von Fieandtin $(1959,58)$ älykkyystestaukseen perustuvat tulokset eivät anna tukea olettamukselle, että maaseudulta Helsinkiin muuttaneet olisivat lahjakkaampia kuin maaseudulla pysyneet. Tutkimuksessa käytetty ei-umpimähkäinen otantamenetelmä tekee tulokset kylläkin varsin epävarmoiksi. Wallander (1948, 
189-193) tutkiessaan kolmen ruotsalaisen kunnan muuttoliikettä vertailee muuttaneiden ja paikallaan pysyneiden kansakoulun päästötodistusten keskiarvoja. Kun vertailu suoritettiin sukupuoli vakioituna, ei muuttaneiden ja paikallaan pysyneiden välillä ollut juuri lainkaan eroja. Vain miesten kohdalla muuttaneiden keskiarvot olivat hieman korkeampia kuin paikallaan pysyneiden. Wallanderin mukaan on kuitenkin mahdollista, että maalaiskunnista kaupunkiin muuttaneet olisivat lahjakkaampia kuin paikallaan pysyneet, kun taas toisiin maalaiskuntiin muuttaneet olisivat vähiten lahjakkaita.

Kaikkein perusteellisimmin näyttää muuttoliikkeen valikoivuutta selvittäneen Neymark (1963), joka on Ruotsissa tutkinut yhtä ikäluokkaa miehiä edustanutta 4500 hengen näytettä. Hänen mukaansa maaseudulta kaupunkiin muuttaneet ovat maaseudulla pysyneisiin nähden selvästi parempia, kun mittoina käytetään perus- ja ammattikoulutuksen määrää, älykkyystestiä, koulukeskiarvoja ja henkisesti jälkeenjääneiden osuutta eri ryhmissä. Neymarkin tulokset ovat hyvin vakuuttavia ja hän täsmentää niitä vielä muuttokohteen suuruuden ja etäisyyden avulla sekä tutkittavien syntyperän mukaan. Seuraavassa pidetään Neymarkin tuloksia lähtökohtana ja oletetaan, että muuttoliike on Ristiinastakin valikoinut keskimääräistä lahjakkaampaa nuorisoa.

Kaikissa esitellyissä tutkimuksissa on tyydytty toteamaan erot muuttaneiden ja paikallaan pysyneiden välillä pyrkimättä teoriaan, joka yhdistäisi tulokset toisiinsa ja muihin sosiologisiin ilmiöihin. Yleensäkin näyttää teorianmúodostus muuttoliiketutkimuksissa olevan vähäistä. Tässäkään artikkelissa ei voida käyttää hyväksi mitään selvää teoriaa. Kun maaseudun uudenaikaistumista ja uudistusten leviämistä koskeva teoria kehittyy (esim. Rogers 1962 ja Benvenuti 1962), on mahdollista ehkä yhdistää muuttovalikointia koskevat tulokset siihen. Kuten Bieler ja Fliegel (1964, 299-300) ovat esittäneet, voidaan maaltamuuttoa ehkä pitää maatalouden uudenaikaistamiseen verrattavana keinona kohonneen vaatimustason saavuttamiseksi. Maatalouden uudenaikaistaminen merkitsee luopumista perinteellisistä menettelytavoista, maaltamuutto taas luopumista perinteellisestä asumisympäristöstä.

\section{Aineisto}

Ristiinan kunta sijaitsee Etelä-Savossa. Kirkonkylästä on noin 20 kilometriä Mikkeliin. Vuoden 1960 väestölaskennan mukaan asui kunnassa 6060 henkeä, joista $63 \%$ sai elantonsa maa- ja metsätaloudesta. Vuodesta 1950 lähtien oli Ristiinan väkiluku alentunut 400 hengellä tappiollisen muuttoliikkeen takia. Muuttaneiden määrä on vaihdellut vuosittain taloudellisten suhdanteiden mukaan samaan tapaan kuin koko maassa.

Tämän tutkimuksen aineisto edustaa Ristiinan nuorisoa. Tutkimuksessa ei kuitenkaan pyritä saamaan tietoja erityisesti Ristiinan muutto- 
liikkeestä, vaan selvittämään yleisesti muuttoon vaikuttavia tekijöitä. Koska niiden voidaan olettaa olevan suunnilleen samanlaisia samanlaisissa olosuhteissa, ovat tulokset ehkä yleistettävissä muuhunkin maaseutuun, joka elinkeinorakenteeltaan ja muilta ominaisuuksiltaan muistuttaa Ristiinaa.

Tutkimusryhmän muodostaa näyte, joka on poimittu Ristiinan kunnan kansakoulujen oppilasluetteloista. Näytteeseen otettiin mukaan kaikki ne, jotka olivat olleet kansakoulun neljännellä luokalla vuosina 1947-50. Näytteeseen tulleet olivat siis tietojen keruun aikana syksyllä 1964 muutamaa poikkeusta lukuunottamatta $24-28$-vuotiaita. Aikaisempien tutkimusten (esim. Lento 1951, 72-73 ja Purola 1964, 71) perusteella oletettiin, että ainakin suurin osa ryhmän yksinmuutoista olisi jo tapahtunut.

Koko näytteen suuruudeksi tuli 464 henkeä, joista perheen mukana oli muuttanut pois Ristiinasta 50 henkeä eli $9 \%$ koko aineistosta. Koska tutkimuksen tarkoituksena oli selvittää nimenomaan nuorison maaltamuuttoon vaikuttavia tekijöitä, keskityttiin vain yksinmuuttoihin ja perheen mukana muuttaneet jätettiin aineiston ulkopuolelle. Samoin poistettiin viisi kuollutta henkilöä ja kuusi henkilöä, joiden muutto jäi lopullisesti selvittämättä. Varsinaiseen nuorison muuton tutkimukseen jäi siis 403 hengen suuruinen näyte.

Koulujen oppilasluetteloista poimittiin tiedot $\mathrm{mm}$. kunkin tutkittavan huoltajan ammatista, IV- ja VII-luokan todistuksen keskiarvosta ja siitä, onko asianomainen siirtynyt oppi- tai ammattikouluun. Kansakoulujen opettajia haastattelemalla selvitettiin edelleen näytteeseen tulleiden ammatti, koulunkäynti, siviilisääty, asianomaisen perheen lapsiluku ja muuttokohde. Opettajat tunsivat useimmiten entiset oppilaansa niin hyvin, että pystyivät antamaan nämä tiedot. Huoltajia ja perheiden taloudellista asemaa koskevat tiedot on poimittu vuoden 1950 veroilmoituksista. Ne koskevat siis tutkimuksen alkuajankohtaa. Tiedot muutosta ja muuttoajankohdasta tarkistettiin Ristiinan kunnan vuosien 1955, 1958, 1962 henkikirjoista. Tutkimuksessa käytetyt muuttoa koskevat tiedot perustuvat siis muuten paitsi muuttokohteen osalta henkikirjoihin. Näin voidaan olla varmoja siitä, että todellinen muuttaneiden määrä ei ole ollut ainakaan pienempi kuin tutkimustulokset osoittavat. Opettajien antamien tietojen mukaan muuttaneiden määrä on hieman suurempi kuin henkikirjan mukainen.

Tutkimusnäytteestä, joka on siis 403 hengen suuruinen, oli vuoteen 1964 mennessä muuttanut pois Ristiinasta 234 henkeä eli $58 \%$ aineistosta. Muuttaneista oli 38 henkeä eli $21 \%$ muuttanut maalaiskuntiin ja loput kaupunkeihin. Kun maaseudulle muuttaneet eivät eroa kaupunkiin muuttaneista sukupuolen, huoltajan ammatin ja oman ammatin suhteen, käsitellään muuttaneita yhtenä ryhmänä. Muuttokohteen merkitystä tutkitaan tarkemmin artikkelin loppuosassa. Tutkimalla muuttaneiden 
ja Ristiinassa pysyneiden välisiä eroja pyritään saamaan selville muuttoalttiutta edistäviä tekijöitä ja erityisesti lahjakkuuden yhteyttä muuttoon. Analyysimenetelmänä käytetään monimuuttujaista ristiintaulukointia. Monimutkaisempien menetelmien kuten diskriminaatioanalyysin käyttö ei tunnu tarkoituksenmukaiselta, koska tärkeimmät muuttujat ovat laadullisia luokituksia (esim. sukupuoli, huoltajan ammatti, muuttokohde). Lisäksi aineisto sisältää eri muuttujien kohdalla melkoisesti puuttuvia tietoja, jotka tuottaisivat monimuuttujamenetelmiä käytettäessä hankaluuksia. Tutkimuksessa ei käytetä systemaattisesti merkitsevyystestausta. Kuten mm. Selvin $(1957,519-527)$ on esittänyt, erillisten riippuvuuksien merkitsevyystestaus syysuhteisiin pyrkivässä survey-tutkimuksessa ei ole tarkoituksenmukaista, koska johtopäätökset perustuvat pääasiassa riippuvuuksien pysyvyyteen ja johdonmukaisuuteen. Tässä tutkimuksessa on merkitsevyystestejä käytetty toisinaan ohjeena ratkaistaessa, kannattaako saatua riippuvuutta täsmentää muiden muuttujien avulla.

\section{Koulumenestys ja muutto Ristrinasta}

Lahjakkuuden vaikutusta muuttoon tutkitaan aluksi käyttäen mittarina koulumenestystä. Mittari on tunnetusti sekä validiteetiltaan lahjakkuuden mittana että reliabiliteetiltaan melko huono (vrt. Vahervuo 1958, 147-157), mutta paremman puutteessa on tässä tyydyttävä siihen. Tutkittavaksi on valittu neljännen luokan todistuksen keskiarvo siksi, että myös oppikouluun siirtyneistä saataisiin muiden kanssa vertailukelpoiset tiedot. Kansakoulun loppuun käyneillä oli seitsemännen ja neljännen luokan todistusten keskiarvojen välinen korrelaatiokerroin 0.64 .

Taulukossa 1 esitetään muuttaneiden osuus koulukeskiarvon mukaan muodostetuista ryhmistä. Taulukosta ilmenee myös muuttaneiden ja paikallaan pysyneiden ryhmäkeskiarvot. Esityksen selventämiseksi keskiarvot on standardisoitu niin, että niiden keskiarvo koko aineistossa on 0 ja hajonta 1 . Tiedot puuttuvat 57 tapauksesta, joita ei ole lainkaan merkitty taulukkoon. Tietojen puuttuminen johtuu koulujen arkistojen puutteellisuuksista eikä siis liene yhteydessä koulumenestykseen tai muuttoon. Tästä syystä tietojen puuttuminen tuskin vaikuttaa olennaisesti tuloksiin.

Koulumenestyksen ja maaltamuuton välillä vallitsee selvä riippuvuus siten, että koulussa hyvin menestyneet ovat muuttaneet keskimääräistä useammin pois Ristiinasta. Riippuvuutta ei voida kuitenkaan suoraan tulkita syysuhteeksi niin, että koulumenestys tai lahjakkuus aiheuttaisi maaltamuuttoa. Riippuvuus voi johtua jostakin sellaisesta tekijästä, joka on yhteydessä molempiin. Sen vuoksi riippuvuutta pyritään täsmentämään muiden muuttujien avulla. 
Ta u l u k k o 1. Muutto koulumenestyksen mukaan.

Table

1. Migration according to success at school.

\begin{tabular}{l|l|l}
\hline $\begin{array}{l}\text { Keskiarvo IV-luokalla - } \\
\text { Average mark in IV grade }\end{array}$ & $\begin{array}{l}\mathrm{N} \\
\text { (ryhmän suuruus) }- \\
\text { (size of group) }\end{array}$ & $\begin{array}{l}\text { Muuttaneita - } \\
\text { Migrants } \\
\%\end{array}$ \\
\hline
\end{tabular}

$\begin{array}{lll}\text { Alle }- \text { below } 6.50 \ldots \ldots \ldots \ldots \ldots \ldots & (69) & 49 \\ 6.50-7.50 & (161) & 58 \\ \text { Yli }- \text { over } 7.50 \ldots \ldots \ldots \ldots \ldots \ldots \ldots & (116) & 66 \\ \text { Yhteensä }- \text { Total } \ldots \ldots \ldots \ldots \ldots \ldots & (346)\end{array}$

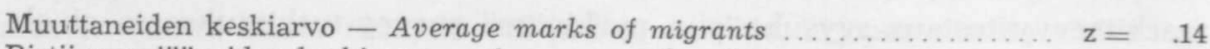
Ristiinaan jääneiden keskiarvo - Average marks of non-migrants ....... $\mathrm{z}=-.18$

Erotus - Difference

$\mathrm{t}=2.43, \mathrm{p}<.01$

Riskitodennäköisyyksiä määrättäessä t-testiä on käytetty yksisuuntaisena, koska Neymarkin tulosten perusteella oletetaan muuttaneiden olevan lahjakkaampia. Tapausten kokonaislukumäärä vaihtelee eri taulukoissa puuttuvien tietojen vuoksi.

In the determination of risk probabilities one-tailed t-test has been applied, since those who migrated were considered to be more gifted on the basis of the findings made by Neymark. In the tables the total number of cases varies because of lack of information.

Ta ulukko 2. Koulumenestyksen ja muuton välinen riippuvuus sukupuoli vakioituna.

Table 2. Relationship between success at school and migration according to sex.

\begin{tabular}{|c|c|c|c|}
\hline & $\underset{\mathrm{N}}{\text { Miehet - Men }}$ & $\begin{array}{cc}\text { Naiset } & \text { Women } \\
\mathrm{N} & \mathrm{z}\end{array}$ & $\begin{array}{l}\text { Erotus } \\
\text { naiset-miehet } \\
\text { Difference } \\
\text { women-men }\end{array}$ \\
\hline $\begin{array}{l}\text { Muuttaneet }- \text { Migrants } \\
\text { Pysyneet }- \text { Non-migrants }\end{array}$ & $\begin{array}{l}-.26 \\
-.51 \\
\end{array}$ & $\begin{array}{l}(119) \\
(55)\end{array}$ & $\begin{array}{l}.70 \\
.84\end{array}$ \\
\hline Yhteensä - Total ....... & -.39 & (174) & .79 \\
\hline Erotus - Difference & $\begin{array}{r}.25 \\
t=1.86 \\
p<\quad .04\end{array}$ & $\begin{array}{r}.11 \\
\mathrm{t}=0.70 \\
\mathrm{p}<.25\end{array}$ & \\
\hline
\end{tabular}

Yleinen käsitys on, että tytöt muuttavat maalta kaupunkeihin enemmän kuin pojat, ja tutkimukset osoittavat samaa (esim. Lento 1951, 71 ja $141-$ 142). Myös tässä aineistossa (taulukko 2) naisten suurempi muuttoalttius tuli selvästi esiin: naisista oli muuttanut $70 \%$, miehistä vain $45 \%$. 
Ta ulukko 3. Muutto sukupuolen ja isän ammatin mukaan. Table

3. Migration according to sex and father's occupation.

\begin{tabular}{|c|c|c|c|c|c|c|}
\hline & \multicolumn{2}{|c|}{$\begin{array}{l}\text { Miehet - } \\
\text { Men }\end{array}$} & \multicolumn{2}{|c|}{$\begin{array}{l}\text { Naiset - } \\
\text { Women }\end{array}$} & \multicolumn{2}{|c|}{$\begin{array}{l}\text { Yhteensä - } \\
\text { Total }\end{array}$} \\
\hline & $\mathrm{N}$ & $\begin{array}{l}\text { Muutta- } \\
\text { neita - } \\
\text { Migrants } \\
\%\end{array}$ & $\mathrm{~N}$ & $\begin{array}{l}\text { Muutta- } \\
\text { neita - } \\
\text { Migrants } \\
\%\end{array}$ & $\mathrm{~N}$ & $\begin{array}{l}\text { Muutta- } \\
\text { neita- } \\
\text { Migrants } \\
\%\end{array}$ \\
\hline \multicolumn{7}{|l|}{ Henkisen työn tekijät - } \\
\hline White collar workers ..... & $(7)$ & 57 & $(9)$ & 67 & ( 16$)$ & 62 \\
\hline $\begin{array}{l}\text { Työväestö - Wage workers } \\
\text { Maanviljelijät - Farmers .. }\end{array}$ & $(66)$ & 53 & ( 65$)$ & 88 & (131) & 70 \\
\hline $\begin{array}{l}\text { Tilan pinta-ala alle } 6 \text { ha }- \\
\text { Size of farm less than } 6 \text { ha } \\
\text { Tilan pinta-ala väh. } 6 \text { ha }\end{array}$ & $(47)$ & 36 & ( 67$)$ & 55 & (114) & 47 \\
\hline Size of farm at least 6 ha & $(58)$ & 36 & ( 39$)$ & 69 & $(97)$ & 49 \\
\hline Yhteensä - Total ........ & (178) & 43 & $(180)$ & 70 & $(358)$ & 56 \\
\hline
\end{tabular}

Naisten enemmyys muuttajista ei ole yleismaailmallinen piirre, vaan useissa maissa miehet muuttavat enemmän kuin naiset (Berelson ja Steiner, 592). Naiset ovat liikkuvampia yleensä yhteiskunnissa, joissa he muutenkin ovat saavuttaneet taloudellisesti ja sosiaalisesti verrattain riippumattoman aseman (Moore, 332). Suomen naisten suuri liikkuvuus voi olla yhteydessä siihen, että meillä naisten osuus myös työvoimasta ja korkeakouluopiskelijoista on kansainvälisesti katsoen korkea.

Sekä miesten että naisten kohdalla muuttaneiden ja Ristiinassa pysyneiden koulumenestyksen erot ovat pienemmät kuin taulukossa 1. Naisten kohdalla ero on melkein kokonaan hävinnyt. Alkuperäinen riippuvuus on siten osittain näennäinen ja johtuu siitä, että tyttöjen koulumenestys on paljon parempi kuin poikien (erotus naiset - miehet) ja että tytöt muuttavat myös koulumenestys vakioituna enemmän kuin pojat. Tyttöjen ja poikien välinen suuri ero ( 0.79 keskihajontaa) koulumenestyksessä osoittaa kouriintuntuvasti käytetyn mittarin yhden heikkouden. Ei voitane ajatella, että tyttöjen ja poikien lahjakkuudessa todella olisi niin suuri ero kuin koulumenestyksessä. Tämän takia on analyysin syytä pitää sukupuoli aina vakioituna.

Toinen tekijä, joka voi olla yhteydessä sekä koulumenestykseen että muuttoon on sosiaaliryhmä, joka tässä määrätään isän tai holhoojan ammatin avulla. Tiedot on saatu koulujen oppilasluetteloista ja veroilmoituksista ja ne ovat melko epätarkkoja. Taulukossa 3 esitetään aluksi Ristiinasta muutto eri sosiaaliryhmissä. Maanviljelijät on tilan koon mukaan jaettu kahteen suunnilleen yhtä suureen ryhmään nim. alle kuuden peltohehtaarin ja vähintään kuuden peltohehtaarin viljelijöihin. 
T a u lukko 4. Koulumenestyksen ja muuton välinen riippuvuus sukupuolen ja isän ammatin mukaan.

Table 4. Relationship between success at school and migration according to sex and father's occupation.

\begin{tabular}{|c|c|c|c|c|c|c|c|c|}
\hline & \multicolumn{4}{|c|}{ Miehet - Men } & \multicolumn{4}{|c|}{ Naiset - Women } \\
\hline & \multicolumn{2}{|c|}{$\begin{array}{c}\text { Maanviljelijät - } \\
\text { Farmers }\end{array}$} & \multicolumn{2}{|c|}{$\begin{array}{l}\text { Muut - } \\
\text { Others }\end{array}$} & \multicolumn{2}{|c|}{$\begin{array}{c}\text { Maanviljelijät - } \\
\text { Farmers }\end{array}$} & \multicolumn{2}{|c|}{$\begin{array}{c}\text { Muut- } \\
\text { Others }\end{array}$} \\
\hline & $\mathrm{N}$ & $\mathrm{z}$ & $\mathrm{N}$ & $\mathrm{z}$ & $\mathrm{N}$ & $\mathrm{z}$ & $\mathrm{N}$ & z \\
\hline $\begin{array}{l}\text { Muuttaneet - } \\
\text { Migrants } . . . \\
\text { Pysyneet - }\end{array}$ & (34) & -.14 & (34) & -.30 & (50) & .30 & (57) & .47 \\
\hline Non-migrants ..... & (55) & -.49 & (29) & -.47 & (37) & .36 & (11) & .34 \\
\hline Yhteensä - Total & (89) & -.36 & (63) & -.38 & (87) & .33 & (68) & .45 \\
\hline Erotus - Difference & & .35 & & .17 & & -.06 & & .13 \\
\hline
\end{tabular}

Ta u lukko 5. Koulumenestyksen keskihajonnat muuton ja sukupuolen mukaan.

Table 5. Standard deviation of school marks according to migration and sex.

\begin{tabular}{|c|c|c|c|c|c|c|}
\hline & $\begin{array}{c}\text { Miel } \\
\text { N }\end{array}$ & $\begin{array}{l}\text { t-Men } \\
\text { Keski- } \\
\text { hajonta }- \\
\text { Standard } \\
\text { deviation }\end{array}$ & $\begin{array}{c}\text { Naiset } \\
\mathrm{N}\end{array}$ & $\begin{array}{l}\text {-Women } \\
\text { Keski- } \\
\text { hajonta - } \\
\text { Standard } \\
\text { deviation }\end{array}$ & $\begin{array}{c}\text { Yhteen } \\
\text { N }\end{array}$ & $\begin{array}{l}\text { - Total } \\
\text { Keski- } \\
\text { hajonta } \\
\text { Standard } \\
\text { deviation }\end{array}$ \\
\hline $\begin{array}{l}\text { Muuttaneet - } \\
\text { Migrants } \\
\text { Pysyneet- } \\
\text { Non-migrants }\end{array}$ & $\begin{array}{l}(81) \\
(91)\end{array}$ & $\begin{array}{l}0.81 \\
0.89\end{array}$ & $\begin{array}{l}(119) \\
(55)\end{array}$ & $\begin{array}{l}0.89 \\
1.02\end{array}$ & $\begin{array}{l}(200) \\
(146)\end{array}$ & $\begin{array}{l}0.95 \\
1.00\end{array}$ \\
\hline Yhteensä - Total & (172) & 0.93 & $(174)$ & 0.95 & $(346)$ & 1.00 \\
\hline
\end{tabular}

Maanviljelijäin lapset muuttavat vähemmän kuin henkisen työn tekijäin ja työväestön lapset. Tämä tulos on yhdenmukainen sen ekologisen tuloksen kanssa, jonka mukaan paikkakunnilta, joissa maatalousväestön osuus on suuri, lähtömuuttaneisuus on keskimääräistä alhaisempi (Purola 1964, 53). Tulos näyttää myös suunnilleen samalta kuin Neymarkin tulos Ruotsissa. Koska aineistossa on henkisen työn tekijäin lapsia kovin vähän, ei heidän ja työväestön lasten muuttoalttiuden välisistä eroista voida sanoa mitään. Tilakoon mukaan muodostettujen maanviljelijäryhmien välillä ei näytä olevan eroja muuttoalttiudessa. Myös muuttaneiden ja pysyneiden keskipinta-alat olivat jokseenkin samat. Sukupuoli vaikuttaa kaikissa 
sosiaaliryhmissä samalla lailla muuttoalttiutta lisäävästi. Erityisesti kiinnittää huomiota se, että työväestön tyttäristä vain $12 \%$ on jäänyt Ristiinaan.

Pienten ryhmien välttämiseksi yhdistetään taulukossa 4 maanviljelijät yhdeksi ryhmäksi ja henkisen työn tekijät työväestön kanssa yhdeksi ryhmäksi.

Kun koulumenestyksen ja muuton välistä yhteyttä tutkitaan sukupuoli ja huoltajan ammatti vakioituna, todetaan, että naisten kohdalla erot muuttaneiden ja pysyneiden välillä ovat edelleen niin pieniä ja epäjohdonmukaisia, että koulumenestyksen ei voida katsoa olevan yhteydessä muuttamiseen. Miehistä maanviljelijäin lasten kohdalla muuttaneet ovat menestyneet koulussa selvästi paremmin kuin paikallaan pysyneet. Työväestön ja henkisen työn tekijäin poikien muodostamassa ryhmässä ero on samaan suuntaan, mutta hyvin pieni. Taulukosta 2 saatua tulosta voidaan siis spesifioida niin, että muuttoliikkeen valikoivuus on voimakkaampi maanviljelijäin poikien kuin muihin sosiaaliryhmiin kuuluvien kohdalla. Tulos on huomionarvoinen, koska myös Neymarkin tutkimuksen (s. 284-285) mukaan muuttovalikointi on voimakkaampaa maanviljelijäin kuin työväestön kohdalla. Hänen tuloksensa perustui älykkyystestillä mitattuun lahjakkuuteen. Neymark olettaa ilmiön johtuvan mm. siitä, että maanviljelijäkodit voivat tarjota työtä heikkolahjaisillekin pojille paremmin kuin työläiskodit.

Siitä, että maanviljelijäkodeista kotoisin olevilla pojilla lahjakkuus vaikuttaa muuttoon enemmän kuin muilla ryhmillä, voidaan ehkä johtaa myös yleisempi hypoteesi. Taulukon 3 ja myös Neymarkin mukaan maanviljelijäin pojat ovat ryhmä, josta muuttaminen on kaikkein harvinaisinta. Voitaisiin ajatella, että muuttovalikointi yleensäkin olisi sitä voimakkaampaa mitä harvinaisempaa muuttaminen jostakin ryhmästä on. Esimerkiksi siis olisivat muuttaneiden ja paikallaan pysyneiden lahjakkuuserot niissä kunnissa, joista muuttaminen on harvinaista, suuremmat kuin kunnissa, joista se on yleisempää.

Edellä on kiinnitetty huomiota vain keskiarvoihin. Kannattaa kuitenkin tarkastella myös lahjakkuuden hajontaa muuttaneilla ja paikallaan pysyneillä (taulukko 5). Toisinaan on nimittäin oletettu, että muuttaneiden joukossa olisi suhteellisen paljon sekä eteenpäin pyrkiviä kaikkein kyvykkäimpiä että heikointa huonosti menestyvää ainesta. Tässä tutkimuksessa se merkitsisi sitä, että muuttaneilla olisi koulukeskiarvojen hajonta suurempi kuin paikallaan pysyneillä.

Olettamus muuttaneiden koulumenestyksen suuremmista hajonnoista ei pidä lainkaan paikkaansa, päinvastoin sekä miehillä että naisilla Ristiinassa pysyneiden koulukeskiarvojen hajonnat ovat hieman suuremmat. Erot ovat kuitenkin niin pienet, että niihin ei kannata kiinnittää enempää huomiota. 


\section{Koulunkäynti ja muutto Ristiinasta}

Edellä on lahjakkuutta pyritty mittaamaan koulumenestyksellä. Toisena mittana käytetään koulunkäynnin määrää. Siihen vaikuttavat ehkä vielä enemmän kuin koulumenestykseen esim. huoltajan varallisuus ja muut sellaiset tekijät, ja sen voidaan ajatella mittaavan nimenomaan hankittuja kykyjä. Taulukossa 6 esitetään prosenttijakaumat tutkittavien koulunkäynnistä.

Taulukossa ei ole mukana niitä henkilöitä, joiden osalta tieto kansakoulun neljännen luokan jälkeisestä koulunkäynnistä puuttuu. Kansakoulun ylittävä koulutus on ollut Ristiinassa varsin harvinaista. Ristiinassa ei ollut tutkittavien ikäluokkien kouluaikana oppikoulua. Sen sijaan kunnassa toimii emäntäkoulu, joka osaksi selittänee sen, että ammattikoulun käyneissä on tyttöjä enemmän kuin poikia. Kuitenkin on hieman yllättävää, että kansakoulun ylittävä koulunkäynti on naisilla ollut selvästi yleisempää kuin miehillä.

Taulukosta 7 ilmenee koulunkäynnin ja muuton välinen yhteys. Sukupuoli on vakioitu, koska sillä on yhteys sekä koulunkäynnin määrään että muuttoon.

Enemmän kuin kansakoulun käyneitä on varsin vähän, joten prosenttiluvuissa voi olla melkoisesti satunnaisvirhettä. Silti voidaan varmasti todeta koulunkäynnin määrän ja muuttoalttiuden välillä vallitsevan erittäin voimakkaan riippuvuuden. Koulunkäynnin vaikutus on selvempi miesten kuin naisten kohdalla, koska enemmän kuin kansakoulun käyneillä sukupuolien välinen muuttoprosenttien ero on paljon pienempi kuin vain kansakoulua käyneillä. Naiset muuttavat koulunkäynnistä riippumatta niin paljon, että koulunkäynti ei vaikuta heidän kohdallaan yhtä paljon kuin miehillä.

Yksi mielenkiintoinen piirre taulukossa on oppikoulua käyneiden suuri muuttoalttius. Vain $15 \%$ niistä, jotka ovat saaneet oppikoulusivistystä, on jäänyt kotikuntaansa. Arvioitaessa tämän tuloksen yleistä merkitystä, on otettava huomioon se, että oppikoulun käynti tutkittujen ikäluokkien osalta oli Ristiinassa harvinaista ja tapahtui kotipaikan ulkopuolella. Paikkakunnilla, joilla oppikoulunkäynti on yleisempää esim. kunnallisen keskikoulun ansiosta, koulunkäynnin vaikutus muuttoon ei ole ehkä yhtä voimakas.

Koulunkäynnin ja muuton välisen riippuvuuden täsmentämiseksi tutkitaan sitä myös huoltajan ammatti vakioituna taulukon 8 avulla.

Koulunkäyntiryhmien väliset erot säilyvät yleensä odotettuina. Poikkeuksen muodostavat työväestön ja henkisen työn tekijäin pojat, jossa ryhmässä vain kansakoulua käyneet ovat muuttaneet yhtä paljon kuin enemmän koulua käyneet. Tulos voi johtua sattumasta, sillä viimeksi mainittuun ryhmään kuuluu vain yhdeksän henkeä. Taulukossa kiinnittää huomiota myös se, että koulunkäynnin vaikutus on voimakkain maan- 
Ta ulukko 6. Koulunkäynnin määrä sukupuolen mukaan.

Table

6. Formal education according to sex.

\begin{tabular}{|c|c|c|c|}
\hline & $\begin{array}{l}\text { Miehet } \\
\text { Men } \\
\text { (168) } \\
\quad \%\end{array}$ & $\begin{array}{l}\text { Naiset } \\
\text { Women } \\
(178) \\
\%\end{array}$ & $\begin{array}{l}\text { Yhteensä } \\
\text { Total } \\
\text { (346) } \\
\%\end{array}$ \\
\hline 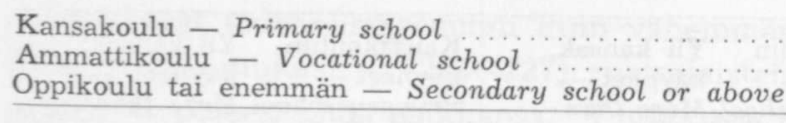 & $\begin{array}{r}86 \\
10 \\
4\end{array}$ & $\begin{array}{l}71 \\
17 \\
12 \\
\end{array}$ & $\begin{array}{r}79 \\
14 \\
7\end{array}$ \\
\hline & 100 & 100 & 100 \\
\hline
\end{tabular}

Ta ulukko 7. Muutto koulunkäynnin ja sukupuolen mukaan.

Table 7. Migration according to formal education and sex.

\begin{tabular}{|c|c|c|c|c|c|c|}
\hline & $\mathrm{N}$ & $\begin{array}{l}\text { Miehet - } \\
\text { Men } \\
\text { Muutto \% - } \\
\text { Migration \% }\end{array}$ & $\mathrm{N}$ & $\begin{array}{l}\text { Naiset - } \\
\text { Women } \\
\text { Muutto \% - } \\
\text { Migration \% }\end{array}$ & N & $\begin{array}{l}\text { Yhteensä - } \\
\text { Total } \\
\text { Muutto \% - } \\
\text { Migration \% }\end{array}$ \\
\hline $\begin{array}{l}\text { Kansakoulu }- \\
\text { Primary school }\end{array}$ & (144) & 42 & (127) & 65 & $(271)$ & 53 \\
\hline & $(18)$ & 61 & $(30)$ & 73 & $(48)$ & 69 \\
\hline $\begin{array}{l}\text { Oppikoulu }- \\
\text { Secondary school }\end{array}$ & $(6)$ & 83 & ( 21$)$ & 86 & ( 27$)$ & 85 \\
\hline Yhteensä - Total . & (168) & 45 & (178) & 70 & $(346)$ & 58 \\
\hline
\end{tabular}

Ta ulukko 8. Koulunkäynnin ja muuton välinen riippuvuus sukupuolen ja isän ammatin mukaan.

Table 8. Relationship between formal education and migration according to sex and father's occupation.

\begin{tabular}{|c|c|c|c|c|c|c|c|c|}
\hline & \multicolumn{4}{|c|}{$\begin{array}{l}\text { Miehet - } \\
\text { Men }\end{array}$} & \multicolumn{4}{|c|}{$\begin{array}{l}\text { Naiset - } \\
\text { Women }\end{array}$} \\
\hline & \multicolumn{2}{|c|}{$\begin{array}{l}\text { Maanvilje- } \\
\text { lijät - } \\
\text { Farmers }\end{array}$} & \multicolumn{2}{|c|}{$\begin{array}{l}\text { Muut - } \\
\text { Others }\end{array}$} & \multicolumn{2}{|c|}{$\begin{array}{l}\text { Maanvilje- } \\
\text { lijät - } \\
\text { Farmers }\end{array}$} & \multicolumn{2}{|c|}{$\begin{array}{l}\text { Muut - } \\
\text { Others }\end{array}$} \\
\hline$\cdots$ & $\mathrm{N}$ & $\begin{array}{l}\text { Muutto \% } \\
\text { Migration } \\
\%\end{array}$ & $\mathrm{~N}$ & $\begin{array}{l}\text { Muutto \% } \\
\text { Migration } \\
\%\end{array}$ & $\begin{array}{ll}N & 1 \\
1 \\
0 \\
1\end{array}$ & $\begin{array}{l}\text { Muutto \% } \\
\text { Migration } \\
\%\end{array}$ & $\mathrm{~N}$ & $\begin{array}{l}\text { Muutto \% } \\
\text { Migration } \\
\%\end{array}$ \\
\hline $\begin{array}{l}\text { Kansakoulu - } \\
\text { Primary school ....... } \\
\text { Enemmän kuin kansa- } \\
\text { koulu - More than } \\
\text { primary school ....... }\end{array}$ & $\begin{array}{l}(74) \\
(14)\end{array}$ & 70 & $\begin{array}{l}(55) \\
(9)\end{array}$ & 56 & $\begin{array}{l}(63) \\
(27)\end{array}$ & 67 & (15) & $\begin{array}{l}84 \\
93 \\
\end{array}$ \\
\hline Yhteensä - Total .... & (88) & 36 & (64) & 55 & $(90)$ & 56 & (66) & 86 \\
\hline
\end{tabular}


Taulukko 9. Koulumenestyksen ja muuton välinen yhteys sukupuolen ja koulunkäynnin mukaan.

Table 9. Relationship between success at school and migration according to sex and formal education.

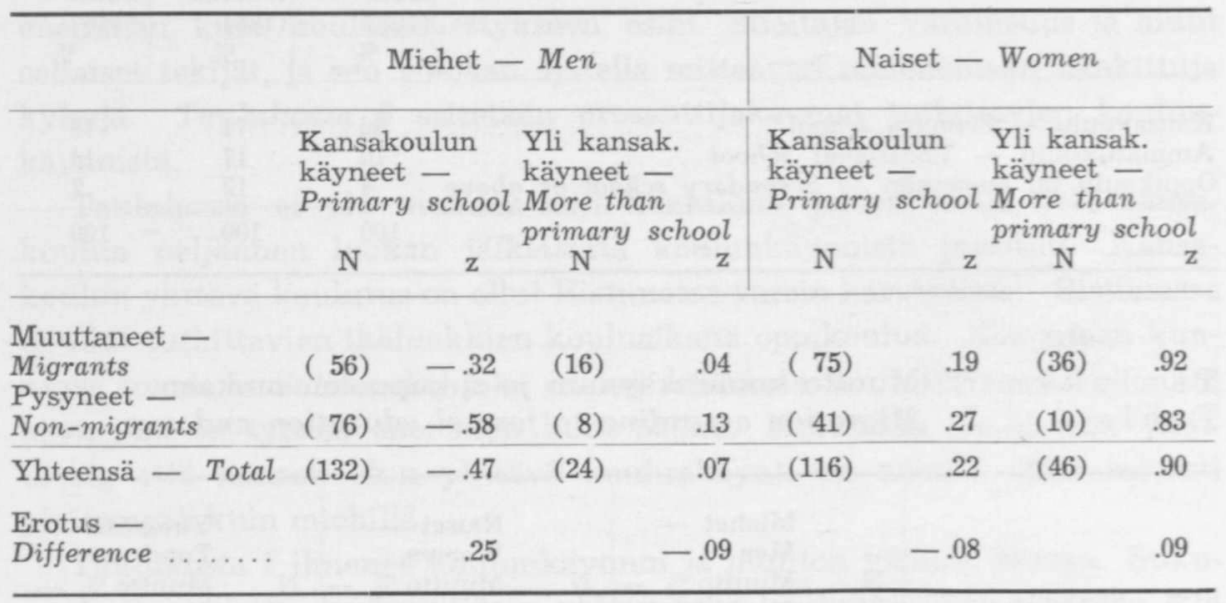

Taulukko 10. Muuttaneiden muuttokohteiden prosenttijakautuma sukupuolen mukaan.

Table 10. Percentage distribution of places of in-migration according to sex.

\begin{tabular}{|c|c|c|c|}
\hline $\begin{array}{l}\text { Muuttokohde - } \\
\text { Place of in-migration }\end{array}$ & $\begin{array}{l}\text { Miehet - } \\
\text { Men } \\
(57) \\
\%\end{array}$ & $\begin{array}{l}\text { Naiset - } \\
\text { Women } \\
(99) \\
\%\end{array}$ & $\begin{array}{l}\text { Yhteensä - } \\
\text { Total } \\
(156) \\
\%\end{array}$ \\
\hline 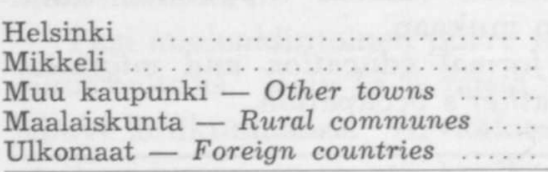 & $\begin{array}{r}25 \\
33 \\
12 \\
23 \\
7\end{array}$ & $\begin{array}{r}21 \\
33 \\
20 \\
21 \\
5\end{array}$ & $\begin{array}{r}22 \\
33 \\
17 \\
22 \\
6\end{array}$ \\
\hline & 100 & 100 & 100 \\
\hline
\end{tabular}

viljelijäin poikien kohdalla. Tulos on yhdenmukainen sen aikaisemmin saadun tuloksen kanssa, että muuttovalikointi koulumenestyksen suhteen on selvintä maanviljelijäin pojilla.

Koulunkäyntiä ja koulumenestystä koskevat tulokset tukevat osittain toisiaan, joskin koulunkäyntiä koskevat tulokset ovat yleensä selvempiä. Koulumenestyksen ja koulunkäynnin vaikutuksen välisestä suhteesta voidaan tehdä kaksi erilaista olettamusta. Voidaan ajatella, että lahjakkuus, joka ilmenee neljännen luokan todistuksessa, johtaa koulunkäynnin jatkamiseen oppi- tai ammattikoulussa, ja tämä koulunkäynti lisää muutto- 
alttiutta. Tällöin koulunkäynti olisi väliintulevana tekijänä prosessissa, joka johtaa siihen, että muuttaneet ovat keskimäärin hieman lahjakkaampia kuin paikallaan pysyneet. Tällöin saman verran koulua käyneiden joukossa muuttaneiden ja paikallaan pysyneiden välillä ei olisi lahjakkuuseroja. Toinen mahdollisuus on, että lisäksi ilmenisi myös "primääristä» muuttovalikointia ts. myös saman verran koulua käyneistä lahjakkaammat muuttaisivat todennäköisemmin kuin vähemmän lahjakkaat. Neymarkin tutkimuksen mukaan (s. 222-227) ruotsalaisten miesten kohdalla jälkimmäinen hypoteesi pitää paikkansa. Taulukossa 9 etsitään vastausta tämän aineiston puitteissa.

Odotetusti enemmän kuin kansakoulua käyneiden koulumenestys sekä miesten että naisten kohdalla on selvästi parempi kuin vähemmän koulua käyneiden (yhteensä rivi). Kun enemmän kuin kansakoulun käyneiden muuttoalttius on suurempi kuin vain kansakoulun käyneiden, valikoituu koulun kautta osa lahjakkaimmista muuttajista. Taulukon mukaan näyttäisi lisäksi kansakoulun käyneiden miesten joukossa tapahtuvan myös primääristä valikoivaa muuttoliikettä. Muuttaneiden koulumenestys on keskimäärin parempi kuin paikallaan pysyneiden, mikä tulos vastaa Neymarkin tulosta. Sen sijaan kaikissa muissa ryhmissä muuttaneiden ja pysyneiden välillä on vain pieniä ja epäjohdonmukaisia eroja.

\section{Muuttokohde}

Opettajilta saatujen tietojen mukaan jakautuvat Ristiinasta muuttaneet muuttokohteen mukaan taulukon 10 osoittamalla tavalla.

Tietoa muuttokohteesta ei ole saatu 61 henkilöltä, jotka on jätetty tarkastelun ulkopuolelle.

Yleisimpänä muuttokohteena on Ristiinaa lähellä oleva Mikkelin kaupunki. Myös Helsinki on saanut vastaanottaa huomattavan osan muuttajista. Miehet ja naiset eivät muuttokohteiden jakautuman suhteen juuri eroa toisistaan. Tulos poikkeaa Allardtin, Jartin, Jyrkilän ja Littusen saamasta (179), jonka mukaan tytöistä suurempi osa kuin pojista muuttaisi maaseudulta kaupunkiin ja pojista taas suurempi osa maaseudulta maaseudulle. Sukupuolten väliset erot heidänkin taulukossaan olivat kuitenkin pieniä.

Neymarkin tulosten mukaan (109-228) olivat koulunkäynti ja älykkyystestillä sekä koulutodistuksella mitattu lahjakkuus yhteydessä muuttokohteeseen niin, että maalaiskunnista suuriin (yli 30000 asukkaan) kaupunkeihin muuttaneet olivat lahjakkaampia kuin pienempiin kaupunkeihin muuttaneet, jotka taas olivat lahjakkaampia kuin maalaiskuntiin muuttaneet. Lisäksi lähelle eli samassa läänissä oleville paikkakunnille muuttaneet olivat vähemmän lahjakkaita kuin kauemmas muuttaneet. Hänen tuloksensa koskivat vain miehiä. Jos Neymarkin tulokset sopisivat tähän aineistoon, pitäisi Helsinkiin ja muihin kaupunkeihin muuttaneiden olla 
T a u lukko 11. Muuttaneiden koulunkäynti ja koulumenestys muuttokohteen mukaan.

$T a b l e$

11. Formal education and success at school of migrants according to place of in-migration.

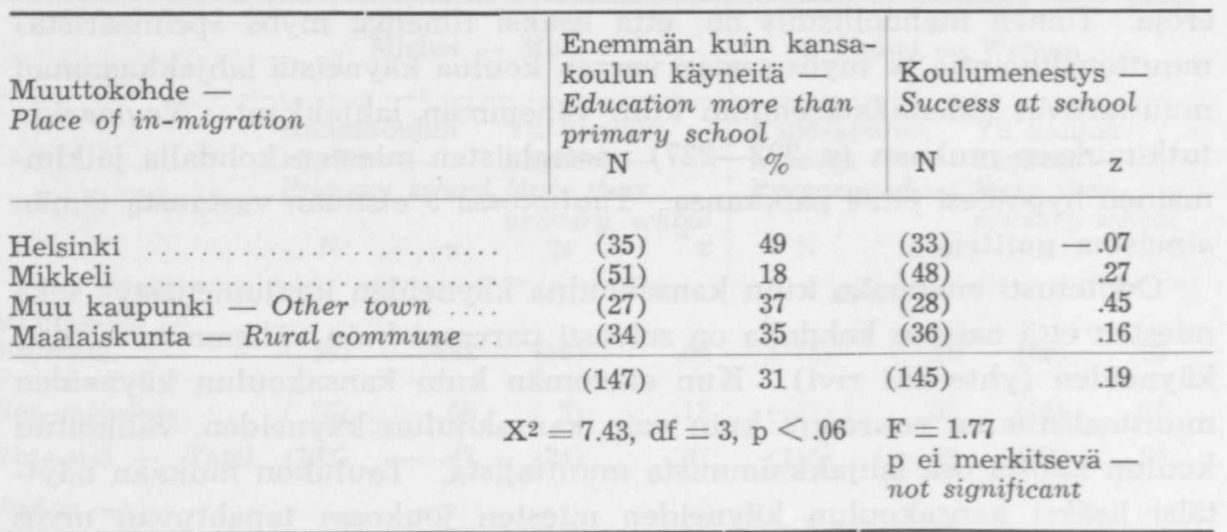

lahjakkaimpia, ts. eniten kouluja käyneitä ja keskimäärin parhaiten koulussa menestyneitä. Maaseudulle muuttaneiden taas pitäisi olla vähiten lahjakkaita. Mikkelin läheisyyden takia lienee oletettava, että sinne muuttaisi vähemmän lahjakkaita kuin muihin kaupunkeihin. Koska monet ryhmät tulisivat muuten liian pieniksi prosenttilukujen laskemista varten, on molempia sukupuolia tarkasteltava yhtä aikaa (taulukko 11). Ulkomaille muuttaneet on jätetty pois, koska ryhmän pienuuden takia heistä ei kuitenkaan olisi voitu tehdä mitään johtopäätöksiä.

Ryhmien koot vaihtelevat, koska puuttuvat tiedot on jätetty huomioonottamatta.

Koulunkäynnin osalta näyttää taulukko hieman antavan tukea Neymarkin tuloksille, koska Helsinkiin muuttaneet ovat eniten kouluja käyneitä. Mikkeliin muuttaneet ovat vähiten kouluja käyneitä, vaikka Neymarkin tulosten mukaan odotettiin maalaiskuntiin muuttaneiden olevan vähiten kouluja käyneitä. Tuloksille ei voitane antaa kovin paljon painoa, koska $\chi^{2}$-testin mukaan eri tyyppisille paikkakunnille muuttaneiden koulunkäyntierot eivät ole tilastollisesti edes melkein merkitseviä.

Koulumenestystä koskevat tiedot tukevat vielä vähemmän Neymarkin tuloksia. Ryhmäkeskiarvot eivät F-testin mukaan eroa toisistaan läheskään merkitsevästi. Erot ovat myös odotusten vastaisesti eri suuntiin kuin koulunkäynnin kohdalla. Sen vuoksi lienee katsottava, että tämän tutkimuksen perusteella ei valikoinnista muuttokohteen suhteen voida sanoa mitään varmaa, vaan asia vaatisi tarkempaa tutkimista suuremmalla aineistolla, jolloin muuttokohteet voitaisiin luokitella tarkemmin. Se, että tässä ei saatu selviä tuloksia, voi johtua myös siitä, että aineiston pienuuden takia ei muuttaneiden sukupuolta voitu valikoida. 


\section{Muita muuttoon vaikuttavia tekijöitä}

Ristiinasta kerätyn aineiston avulla saadaan jo esitettyjen lisäksi muitakin tuloksia muuttoon vaikuttavista tekijöistä. Niihin ei voida kuitenkaan tässä artikkelissa yksityiskohtaisesti puuttua, vaan tyydytään luettelemaan lyhyesti tärkeimmät niistä. Tarkemmat tiedot ja taulukot on esitetty Kaisa Kukkosen pro gradu-työssä.

1. Muualla kuin Ristiinassa syntyneet ovat muuttaneet useammin kuin spaljasjalkaiset» ristiinalaiset. Tämä tulos sopii hyvin Berelsonin ja Steinerin (591) esittämään muuttoliikkeen kasautumista koskevaan yleistykseen: aikaisemmin muuttaneiden muuttotodennäköisyys on suurempi kuin paikallaan pysyneiden. Tulos voitaneen kuitenkin osaksi selittää myös huoltajan ammatin avulla. Muualta Ristiinaan muuttaneet ovat tavallisesti työväestöä tai henkisen työn tekijöitä, joiden lasten muuttoalttius on yleensä suurempi kuin maanviljelijäin lasten.

2. Perheen lapsiluvun ollessa suuri, muuttoalttius on korkeampi kuin lapsiluvun ollessa pieni. Riippuvuus on selvempi maanviljelijäperheissä kuin muilla, mutta lapsiluvun váikutus ei ole kovin suuri missään ryhmässä.

3. Tutkittavien siviilisäädystä ennen muuttoa ei ole tietoa. Tutkimuksen suorittamisajankohtana oli muuttaneista naimisissa $58 \%$ ja Ristiinassa pysyneistä $36 \%$. Ero johtunee osittain siitä, että naiset menevät naimisiin nuorempina kuin miehet. Kuitenkin näyttää myös siltä, että joko muuttaminen lisää avioliittomahdollisuuksia tai muuttaneilla on sellaisia ominaisuuksia, jotka edistävät avioliiton solmimismahdollisuuksia.

4. Muuttaneista työväestön lapsista oli $33 \%$ noussut henkisen työn tekijöiksi, kun taas Ristiinassa pysyneistä työväestön lapsista vain $9 \%$ oli tutkimuksen suorittamisen aikana henkisen työn tekijöitä. Muuttaminen on siis huomattavalle osalle merkinnyt sosiaalista kohoamista. Tietojen epätarkkuuden vuoksi tässä ei vielä edes tule esille kohoamista ammattitaidottoman metsä- tai rakennustyömiehen lapsesta ammattitaitoiseksi työntekijäksi, mikä myös lienee melko yleistä. Muuttaneista maanviljelijäin lapsista $48 \%$ oli tullut henkisen työn tekijöiksi, pysyneistä vain $6 \%$, joten myös heillä muuttaminen erittäin usein on ollut yhteydessä sosiaaliseen kohoamiseen. Kun oppikoulun käynti on ollut harvinaista, ei se yksin selitä tätä, vaan ilmiö lienee yhteydessä muunlaiseen muuttovalikointiin ja kaupunkien parempiin sosiaalisen nousun mahdollisuuksiin.

5. Veroilmoitusten perusteella mitatulla huoltajan tulotasolla ei näyttänyt olevan yhteyttä muuttoalttiuteen. Korkeintaan on havaittavissa lievää epälineaarisuutta niin, että toisaalta pienituloisimpien toisaalta suurituloisimpien vanhempien lapset muuttavat eniten. Tämä yhteys voitaneen selittää niin, että pienituloisimpien vanhempien lasten on pakko lähteä maailmalle onneaan eli työtä etsimään. Suurituloisimpien lapset taas saavat enemmän koulutusta tai oppivat muuten perheympäristössään uudenaikai- 
sia kaupunkimaisia arvoja ja päämääriä ja ovat sen takia alttiita muuttamaan. Tämä ja eräät muutkin tulokset näyttäisivät viittaavan siihen, että Bielerin ja Fliegelin esittämä ajatus maaltamuutosta uudenaikaistumisilmiönä antaa tutkimisen arvoisia hypoteeseja vain niiden kohdalla, joilla olisi mahdollisuuksia toimeentuloon kotipaikkakunnallaankin.

\section{Tiivistelmä tuloksista}

Tutkimuksessa käytettyjen taustamuuttujien vaikutuksesta muuttoon todettiin, että naisten muuttoalttius on suurempi kuin miesten ja maanviljelijäin lasten pienempi kuin muiden. Kodin varallisuuden suhteen eivät muuttaneet keskimäärin eronneet paikallaan pysyneistä.

Sukupuoli ja huoltajan ammatti vaikuttavat sekä koulunkäyntiin että koulumenestykseen. Tämä yhdessä aineiston pienuuden kanssa aiheutti sen, että oli vaikea saada varmoja tuloksia lahjakkuuden vaikutuksesta muuttoon. Kansakoulun ylittävä koulunkäynti kuitenkin lisäsi muuttoalttiutta huomattavasti kaikissa ryhmissä. Koulunkäynnin vaikutus muuttoon oli lisäksi voimakkaampi miehillä kuin naisilla. Koulumenestyksen osalta tulokset eivät olleet yhtä selviä, mikä johtunee osaksi kouluarvosanojen seka-aineksisuudesta ja alhaisesta reliabiliteetista. Miesten kohdalla olivat muuttaneet koulumenestyksellä mitaten hieman lahjakkaampia kuin paikallaan pysyneet. Ero oli selvempi maanviljelijäin kuin työväestön ja henkisen työn tekijäin pojilla. Koulumenestys ei miehillä vaikuttanut muuttoon pelkästään koulunkäynnin kautta, sillä vain kansakoulun käyneistä miehistä olivat muuttaneet menestyneet keskimäärin paremmin kuin paikallaan pysyneet. Näiden tulosten luotettavuutta ja yleistettävyyttä lisää huomattavasti se, että ne ovat pääkohdissaan samoja kuin Neymarkin ruotsalaisilla miehillä saamat. Naisilla ei koulumenestyksen ja muuton välillä ollut yhteyttä. Naisten maaltamuutto näyttää siis osittain poikkeavan syiltään miesten maaltamuutosta.

Tutkimuksessa ei voitu osoittaa eroja eri tyyppisille paikkakunnille muuttaneiden välillä. Tässä kohdin tulokset erosivat Neymarkin tuloksista.

Olettamus, että muuttaneissa olisi suhteellisen paljon kaikkein lahjakkaimpia ja kaikkein vähälahjaisimpia, ei saanut tutkimuksesta tukea. Sen sijaan oli havaittavissa, että muuttaneissa oli jonkin verran yliedustettuna toisaalta vähävaraisimpien ja toisaalta varakkaimpien lapset. Muuttaneissa oli selvästi enemmän sosiaalisesti kohonneita kuin paikallaan pysyneissä, mikä lienee yhteydessä muuttoliikkeen valikoivuuteen. Suurempi osa muuttaneista kuin paikallaan pysyneistä oli myös solminut avioliiton.

Tutkimuksessa on monia puutteellisuuksia, jotka heikentävät tulosten luotettavuutta. Ensinnäkin näyte edustaa vain yhden paikkakunnan nuorisoa, eikä tiedetä missä määrin saadut tulokset ovat yleistettävissä muualle. 
Toiseksi tutkimuksessa on täytynyt tyytyä varsin puutteellisiin muuttujiin ja mittareihin, joita on voitu saada valmiista aineistosta. Lisäksi aineiston pienuus on pahasti rajoittanut analyysia. Ongelman tarkempi tutkiminen suuremmalla koko maata edustavalla näytteellä ja paremmin rakennetuilla mittareilla olisi sen vuoksi tarpeellista. Tällöin olisi myös pyrittävä kehittämään maaltamuuttoa koskevaa teoriaa, joka auttaisi yhdistämään tulokset toisiinsa ja muihin sosiologisiin tuloksiin. Maaltamuuttoa koskevien tuloksien merkitys ei ehkä kuitenkaan olisi ensisijaisesti teoreettinen. Ne olisivat hyvin tärkeitä myös esim. Suomen kehitysalueita ja hajasijoitusta koskevassa yhteiskuntapoliittisessa keskustelussa ja suunnittelussa.

\section{Kirjallisuus}

Allardt, E.-Jartti, P. - Jyrkilä, F. - Littunen, Y. Nuorison harrastukset ja yhteisön rakenne, Porvoo 1958.

Bealer, R. C. - Fliegel, F. C. A Reconsideration of Social Change, Our Changing Rural Society, toim. James H. Copp, Ames, Iowa 1964.

Benvenuti, B. Farming in Cultural Change, Assen 1962.

Berelson, B. - Steiner, G. A. Human Behavior, An Inventory of Scientific Findings, New York 1964.

von Fieandt, K. Helsingin paljasjalkaiset ja uusi asuttajapolvi, Helsinki 1958.

Kukkonen, K. Nuorison maaltamuutto, tutkimus nuorison muutosta Ristiinan kunnassa vuosina $1950-63$, sosiologian pro gradu-tutkielma, Helsingin yliopisto 1965 .

Lento, R. Maassamuutto ja siihen vaikuttavat tekijät Suomessa 1878-1939, Helsinki 1951.

Moore, W. E. Industrialization and Social Change, toim. Hoselitz ja Moore. Unesco Mouton, 1963.

Neymark, E. Selektiv rörlighet. Flyttningstendenser och yrkesval i relation till utbildning, begåvning och härkomst, Stockholm 1961.

Purola, T. Maassamuuton vilkkaus, Helsinki 1964.

Rogers, E. M. Diffusion of Innovations, Glencoe 1962.

Selvin, H. A critic of tests of significance in survey research, American Sociological Review, 22, 1957, 519-527.

Vahervuo, T. Arvosanojen antamisesta, Keuruu 1958.

Valkonen, T. Perinteellisestä uudenaikaiseen. Tutkimus yhteisön ja yksilöiden uudenaikaistumisesta Ristiinassa, Helsingin yliopiston sosiologian laitoksen julkaisuja n:o 55, 1965.

\section{Summary:}

\section{Factors in rural out-migration}

By TAPANI VALKONEN and KAISA KUKKONEN, Institute of Sociology, University of Helsinki

This article is concerned with the factors affecting rural out-migration of youth: a special endeavor is made to ascertain whether young people who have moved from the countryside into towns are more gifted than the average. The data were compiled in 
the commune of Ristiina, where the Institute of Sociology of the University of Helsinki is engaged in a longitudinal study of the influence of industrialization. Ristiina is primarily an agrarian community: in 1960, 63 per cent of the population was engaged in agriculture.

The sample was drawn from the registers of primary schools: all those attending the fourth grade between $1947-50$ have been picked out, the final number of pupils included in the study amounting to 403. Information was obtained from the school registers, the census lists, taxation rolls, and by means of interviews with teachers who supplied details about the pupils selected: for example, their success at primary school, their subsequent education, whether and where they had moved to from Ristiina, along with their parents' financial situation.

Fifty-eight per cent of the sample, (234 pupils) had moved from Ristiina by 1964. The difference between those who had moved from Ristiina and those who remained have been compared in order to elucidate the factors which had influenced migration, especially the relationship between being gifted and migration.

The relationship between migration and the background variables selected in this study indicated that women were more disposed to move than men, and that the children of farmers were less inclined to do so than others. The financial circumtances of the homes had no effect on the average number of those who migrated and those who stayed.

Education beyond primary school appreciably increased the disposition to move in all groups. The influence of education on migration was more marked among men than among women. Partly because of the low reliability of the school marks the results concerning success at school are not quite conclusive. From the standpoint of school success, men who had migrated were, on the average, more gifted than those who stayed. The difference was more obvious among sons of farmers than among sons of white collar workers. In case of men success at school not only affected amount of education but migrant men with only primary school education also had better marks than those who did not migrate from Ristiina. The reliability and generalizibility of these findings is supported by the fact that on the whole they correspond with the results found by Neymark in his study of Swedish males. As far as women are concerned no relationship was found between school success and migration. Thus in part the migration of women from the countryside seems to differ from that of men.

The study did not indicate any difference among those who had moved to places of various types. In this respect, the findings diverged from those of Neymark.

The assumption that among out-migrants comparatively many were either very gifted or very ungifted has not been borne out by this study, although it was shown that the majority of those moving represented the children of indigent parents, on the one hand, and the children of well-to-do parents, on the other. Of those who had moved, the majority had advanced socially: this appears to be related to the factors influencing migration. There were more married people among those who had migrated than among those who had not. 